\title{
Antibacterial Activity of Cationic Proteins from Human Granulocytes
}

\author{
H. Odeberg and I. Olsson \\ From the Department of Internal Medicine, Research Laboratory for Clinical \\ Hematology and Dalby Community Health Research Centre, \\ University of Lund, Lund, Sweden
}

A B S T R A C T Human granulocytes contain several cationic proteins with a molecular weight of approximately 25,000, almost identical amino acid composition, and complete immunologic identity. These proteins possess a chymotrypsin-like protease activity at a neutral $\mathrm{pH}$. The antibacterial activity of the cationic proteins has been studied. Bactericidal activities are found against both Gram-positive (Streptococcus faecalis and Staphylococcus aureus) and Gram-negative (Escherichia coli and Pseudomonas aeruginosa) organisms. Gram-positive bacteria are, however, the most sensitive. The $\mathrm{pH}$ optimum is near neutrality, and the microbicidal activity shows an inverse relationship to the ionic strength, indicating an ionic interaction between the cationic proteins and the bacterial surface. The microbicidal effect of the cationic proteins is generally independent of the chymotrypsin-like activity of the same proteins since the activity against several bacterial species is heat stable while the chymotrypsin-like activity is heat labile. The surface properties of $S$. aureus that are determined by protein A do not seem to influence the susceptibility to cationic proteins. The properties of the Gram-negative envelope of $E$. coli that determine the susceptibility to the lytic action of serum do not influence the sensitivity to the action of cationic proteins. The present study shows that cationic proteins of human granulocytes represent one potential microbicidal mechanism that is independent of hydrogen peroxide and myeloperoxidase.

\section{INTRODUCTION}

Microbial killing in granulocytes follows ingestion of microorganisms into the cell. Killing takes place in the phagocytic vacuole after release of the microbicidal fac-

Received for publication 17 March 1975 and in revised form 14 July 1975. tors of the cytoplasmic granules. The increased production of hydrogen peroxide, linked to an increase in oxygen consumption and hexose monophosphate shunt activity, constitutes, together with myeloperoxidase, one microbicidal system (1). Information is, however, still scarce concerning the actual mechanism of bacterial killing in granulocytes (2). Prolonged intracellular survival of some microorganisms, e.g. Staphylococcus aureus, results under conditions of defective hydrogen peroxide production as in chronic granulomatous disease of childhood (CGD) ${ }^{1}$ (3). Other organisms, e.g. Streptococci (4), Lactobacilli (5), and Pneumococci (6), are readily killed even in CGD granulocytes. Furthermore, individuals deficient in myeloperoxidase usually do not have excessive infections, and their granulocytes kill ingested bacteria, although at a reduced rate $(7,8)$. Therefore, alternative microbicidal mechanisms might exist that do not involve the myeloperoxidase-hydrogen peroxide system.

A bactericidal agent of rabbit granulocytes, phagocytin, was described by Hirsch (9) and shown by Zeya and Spitznagel (10) to consist of highly cationic proteins with different degrees of antimicrobial capacity against the bacterial species studied. Previous work from our laboratory has demonstrated cationic proteins to be present also in human granulocytes (11). One group of cationic proteins (components 1-4) shows molecular weights of $25,500-28,500$, almost identical amino acid composition, and immunochemical identity. The other group of proteins (components 5-7) demonstrate molecular weights of 21,000-29,000 and immunological identity. Recently, Lehrer et al. (12) have identified a nonperoxidative fungicidal mechanism in human granulocytes. Fungicidal proteins with esterase activi-

\footnotetext{
${ }^{1}$ Abbreviations used in this paper: CGD, chronic granulomatous disease of childhood; HEPES, $N$-2-hydroxyethylpiperazine- $N^{\prime}$-2-ethane sulfonic acid; KRP, KrebsRinger phosphate buffer.
} 
ties separated by micro-preparative electrophoresis seem to have properties identical with some of our purified cationic proteins. Similarly, Rindler and Braunsteiner (13) have also demonstrated the presence of cationic esterases in human granulocytes. It is the purpose of the present communication to report studies on the antimicrobial capacity of the cationic proteins obtained from human granulocytes.

\section{METHODS}

Microorganisms. S. aurcus 502A, Streptococcus faecalis ATCC no. 8043, and clinical isolates from urine of Escherichia coli, Pseudomonas aeruginosa, and $S$. faecalis are used in the bactericidal assays. $S$. aureus $502 \mathrm{~A}$ is maintained on CCY Medium (14) solidified with $1.5 \%$ Bacto agar, $S$. faecalis ATCC no. 8043 was cultured on Bacto microassay culture agar (Difco Laboratories, Detroit, Mich.), and the other organisms are maintained on blood agar. Stock cultures are passed every 2nd to 4th wk.

Cationic proteins. The cationic proteins are isolated from human leukocyte granule extracts as previously described (11). These proteins are numbered 1-7, and component 1 is the most cationic component with the highest electrophoretic mobility towards the cathode. In the present report only the group of the most cationic protein components $1-4$ is studied. Components 2 and 3 are the major ones while components 1 and 4 usually are present only in small amounts. For the present purpose these components have not been completely purified. Instead two fractions are used; one fraction containing a mixture of components 1 and 2 (A) and the other containing a mixture of components 3 and 4 (B). The electrophoretic pattern on agarose gel of the fractions used is shown in Fig. 1.

Bactericidal assay. Bacteria are grown in Bacto antibiotic medium 3 (Difco Laboratories) at $37^{\circ} \mathrm{C}$ overnight, except for $S$. faecalis ATCC no. 8043 which is grown in Bacto folic assay medium fortified with $1 \mathrm{ng}$ per $\mathrm{ml}$ pteroylglutamic acid. To obtain bacteria in the logarithmic growth phase, $0.1 \mathrm{ml}$ of the overnight broth culture is transferred to $5 \mathrm{ml}$ of fresh antibiotic medium 3 and incubated at $37^{\circ} \mathrm{C}$. The OD of the broth cultures is followed at $628 \mathrm{~nm}$, and the organisms are harvested during logarithmic growth, washed twice in $5 \mathrm{ml}$ of calcium-free Krebs-Ringer phosphate buffer (KRP), $\mathrm{pH} 7.4$, containing $0.1 \%$ gelatin, and resuspended in KRP to an OD of 0.23 at $628 \mathrm{~nm}$, corresponding to $2.0-3.0 \times 10^{8}$ organisms per $\mathrm{ml}$. Bacteria are then suspended in a modified Hanks' balanced salt solution to a concentration of about $2.5 \times$ $10^{6}$ organisms per $\mathrm{ml}$, and a water solution of cationic protein is added. The final concentration of solutes in the incubation mixtl:e is $67 \mathrm{mM} \mathrm{NaCl}, 3.5 \mathrm{mM} \mathrm{NaHCO}$, $4.2 \mathrm{mM} \mathrm{KCl}, 1.0 \mathrm{mM} \mathrm{CaCl}, 0.32 \mathrm{mM} \mathrm{MgSO}_{4}, 0.39 \mathrm{mM}$ $\mathrm{MgCl}_{2}, 0.27 \mathrm{mM} \mathrm{Na}_{2} \mathrm{HPO}_{4}, 0.35 \mathrm{mM} \mathrm{KH}_{2} \mathrm{PO}_{4}, 4.4 \mathrm{mM}$ glucose, $16 \mathrm{mM} N$-2-hydroxyethylpiperazine- $N^{\prime}$-2-ethane sulfonic acid (HEPES), $\mathrm{pH} 7.4$, and gelatin $0.1 \%$. The mixtures are incubated in $12 \times 75-\mathrm{mm}$ plastic tubes (Falcon Plastics, Division of BioQuest, Oxnard, Calif.) during rotation end-over-end at the rate of $20 \mathrm{rpm}$ at $37^{\circ} \mathrm{C}$. Controls are run without cationic protein. For determination of the number of surviving bacteria by the pour plate method, aliquots of 20-200 $\mu \mathrm{l}$ are removed at 0,30 , and $60 \mathrm{~min}$ and diluted in $8 \mathrm{ml} \mathrm{KRP}$ containing $0.1 \%$ gelatin. Samples are mixed with Bacto antibiotic medium 3 containing $1.5 \%$ Bacto agar, and the number of colony-forming units is determined after incubation overnight. The number of sur-

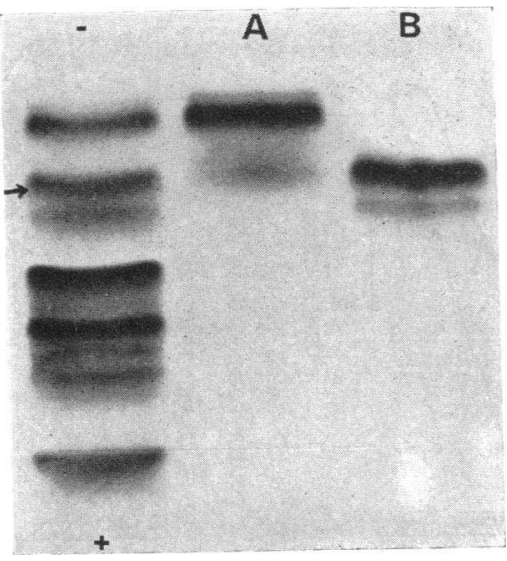

Figure 1 Agarose gel electrophoresis of the cationic protein fractions used in the present study (A and $B$ ). The cationic protein-enriched fraction obtained by gel chromatography (11) is shown for reference. The arrow indicates the electrophoretic mobility of lysozyme.

viving bacteria is also determined by OD readings at 628 $\mathrm{nm}$. For this purpose, $4 \mathrm{ml}$ of broth is added to the 60 min incubations, and the OD followed until a stationary growth phase is achieved. The time for attainment of an $\mathrm{OD}$ of 0.40 is determined. The time difference between cationic protein incubation and control incubation is divided by the mean generation time (MGT) obtained from the OD readings, and the number obtained is designed "MGT." The exponential growth rates are identical in control and cationic protein incubations. The number of surviving bacteria in the 60 -min incubation mixture with catonic protein is calculated from the following formula: Surviving bacteria (cationic protein) = surviving bacteria (control)/ $2^{\text {(dMGT). }}$ The number of surviving bacteria in the control incubation used in the formula is determined by colony count using the pour plate method.

\section{RESULTS}

The cationic protein fractions $A$ and $B$ both exhibit antibacterial activities against several species tested. Fig. 2 shows an experiment with $S$. aureus and $E$. coli. After incubation with cationic protein $\mathrm{A}$ for $60 \mathrm{~min}$ in the standard incubation medium, broth is added to the mixture, which is incubated at $37^{\circ} \mathrm{C}$. Both colony counts and $O D$ readings are used for determination of the bacteria concentration after different time periods.

The number of colony-forming units is significantly decreased after $60 \mathrm{~min}$ incubation with cationic proteins. The 60 -min control incubations contain $1.2 \times 10^{\circ}$ (S. aureus) and $5.0 \times 10^{\circ}$ (E. coli) colony-forming units per $\mathrm{ml}$ whereas the figures for the cationic protein incubations are $9.2 \times 10^{4}$ ( $S$. aureus) and $9.8 \times 10^{4}$ (E. coli). When calculated from OD readings according to the formula given in methods the number of surviving bacteria in the 60 -min incubation with cationic protein is $5 \times 10^{4}$ ( $S$. aureus) and $1.5 \times 10^{5}$ (E. coli) organisms per $\mathrm{ml}$. The increase in $\mathrm{OD}$, followed during the latter part of the 

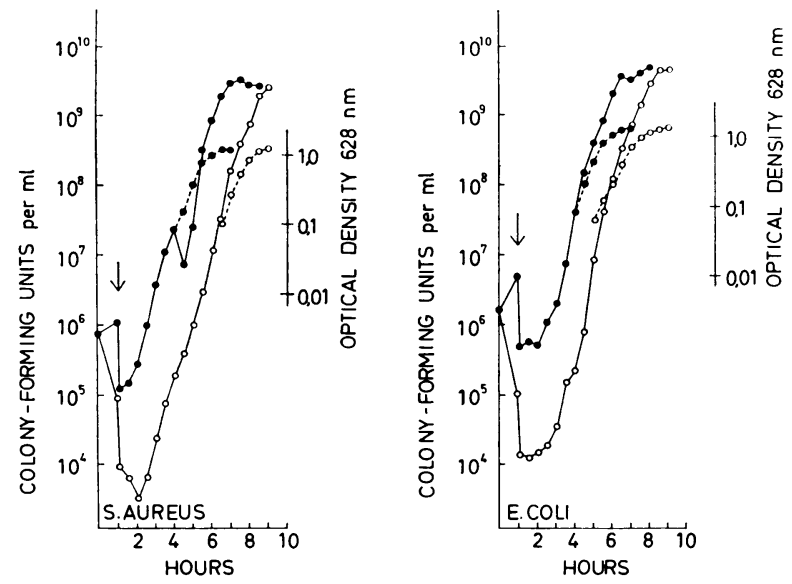

Figure 2 Antimicrobial effect of cationic protein A on $S$. aureus and $E$. coli. Bacteria are incubated with $54 \mu \mathrm{g} / \mathrm{ml}$ (S. aureus) and $108 \mu \mathrm{g} / \mathrm{ml} \mathrm{(E.} \mathrm{coli)} \mathrm{for} 60 \mathrm{~min}$. After that (indicated by arrow) $4 \mathrm{ml}$ of broth is added both to control incubation (-) and to cationic protein incubation $(\mathrm{O}-\mathrm{O})$ and the mixtures are incubated at $37^{\circ} \mathrm{C}$. The growth of the organisms is followed both by colony counting $(-)$ and by OD readings (--).

exponential growth phase after addition of broth, is somewhat lower than the increase in colony-forming units, leading to an overestimation of the number of surviving bacteria when calculated from OD readings. On the other hand, the number of surviving bacteria after $60 \mathrm{~min}$ is underestimated if killing continues after the addition of broth as is the case for S. aureus (Fig. 2 ). Thus, identical results cannot be expected when the number of surviving bacteria is determined with colony counting and OD readings. In the experiments to be described below, aliquots are taken for colony counts after incubation of organisms with cationic proteins for 30 and $60 \mathrm{~min}$. After addition of broth to the incubation mixtures the increase in OD is also followed and compared with the increase of OD of a control incubation with bacteria not subjected to the action of cationic protein as described in methods. In all instances the information obtained by colony counts and OD readings agreed fairly well. Below, only the results from the colony count method are documented.

In Fig. 3 the effect of $\mathrm{pH}$ on the antibacterial activity of cationic protein $\mathrm{A}$ is demonstrated. The $\mathrm{pH}$ of the standard incubation medium is varied from 6.0 to 7.8 with HEPES buffer. At $\mathrm{pH}$ 6-7 only slight killing is found. The activity is highly increased with a $\mathrm{pH}$ above 7. Identical results are obtained with $S$. aureus and $E$. coli. For the attainment of $\mathrm{pH}$ levels below 6.0 and above 7.8 2-( $N$-morpholino $)$ ethane sulfonic acid buffer and Tris buffer, respectively, is used. At $\mathrm{pH}$ 5.0-6.0 the microbicidal activity is almost identical with that of $\mathrm{pH}$ 6.0-7.0. Increasing the $\mathrm{pH}$ above $\mathrm{pH} 7.8$ gives a further increase of the microbicidal activity with $\mathrm{pH}$ (results not shown).

The effect of the ionic strength on the antibacterial activity of cationic protein $\mathrm{A}$ is studied by the addition of increasing amounts of sodium chloride (Fig. 3). The microbicidal effect shows an inverse relationship to the ionic strength. At an ionic strength corresponding to $0.2 \mathrm{M}$ sodium chloride or higher the microbicidal activity is abolished. In the standard incubation procedure for assay of antibacterial capacity an ionic strength corresponding to $0.09 \mathrm{M}$ sodium chloride is chosen. This concentration is a little below the ionic strength of serum that corresponds to $0.12 \mathrm{M}$ sodium chloride as measured by conductivity. It is also demonstrated that the antimicrobial activity is abolished when, after incubation for $30 \mathrm{~min}$ in the standard incubation medium, the concentration of sodium chloride is increased to $0.2 \mathrm{M}$ (Fig. 4); the antibacterial activity is promptly inhibited by increasing the ionic strength.

The microbicidal activity of the cationic proteins against several microbial species are compared in Figs. 5 and 6. The effects of both cationic protein A (components 1 and 2) and $B$ (components 3 and 4) are examined. It is found that the cationic proteins exhibit
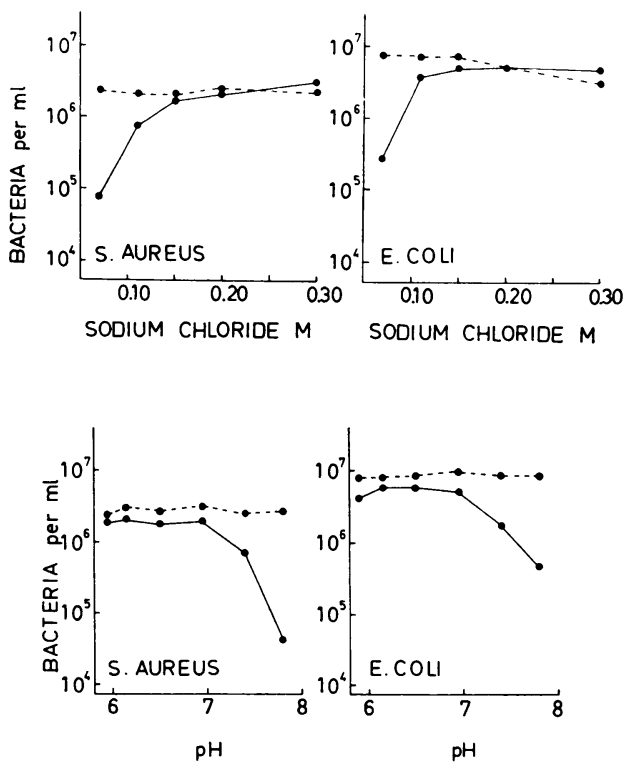

FIgURE 3 Effect of ionic strength and $\mathrm{pH}$ on the microbicidal activity of cationic protein A. For studies on ionic strength, bacteria are incubated with $80 \mu \mathrm{g} / \mathrm{ml}$ ( $S$. aureus) and $108 \mu \mathrm{g} / \mathrm{ml}$ (E. coli) in the standard incubation medium where the $\mathrm{NaCl}$ concentration is varied (- $-\bullet)$. Controls are run without cationic protein $(\bullet--\bullet)$. For studies of $\mathrm{pH}$ effect, bacteria are incubated with $50 \mu \mathrm{g} / \mathrm{ml}$ (S. aureus) and $80 \mu \mathrm{g} / \mathrm{ml} \mathrm{(E.} \mathrm{coli)} \mathrm{in} \mathrm{the} \mathrm{standard} \mathrm{incubation} \mathrm{medium}$ where the $\mathrm{pH}$ is varied between 6 and 7.8 by the addition of HEPES buffer $(\bullet-\bullet)$. 


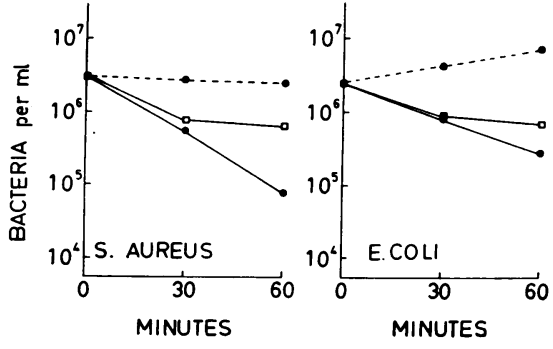

FIgURE 4 Effect of ionic strength on the microbicidal activity of cationic protein A. Bacteria are incubated with

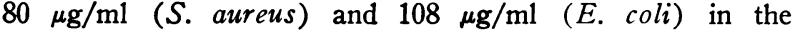
standard incubation medium (-૯). After $30 \mathrm{~min}$ of incubation $\mathrm{NaCl}$ is added to a final concentration of $0.2 \mathrm{M}$ $(\square-\square)$. Controls are also run without cationic protein $(\bullet--\bullet)$.

an antibacterial effect against both Gram-positive ( $S$. faecalis and $S$. aureus) and Gram-negative species ( $E$. coli and $P$. aeruginosa). It is apparent that the Grampositive bacteria studied are more sensitive to the action of the cationic proteins than are Gram-negative bacteria.

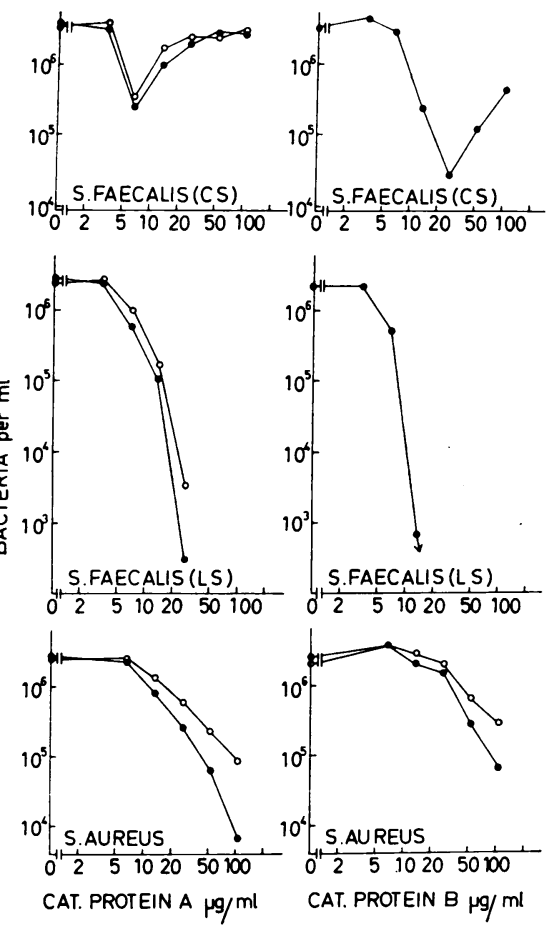

FIGURE 5 Antimicrobial effect of different concentrations of cationic protein A and B on $S$. aureus, $S$. faecalis ATCC 8043 (laboratory strain [LS]), and a clinical strain (CS) of $S$. faecalis. Surviving bacteria are determined by colony counting at $30 \mathrm{~min}(\mathrm{O}-\mathrm{O})$ and $60 \mathrm{~min}(--)$ of incubation. The results shown to the left in the figure are from incubations with cationic protein $A$ and results shown to the right are from incubations with cationic protein B.

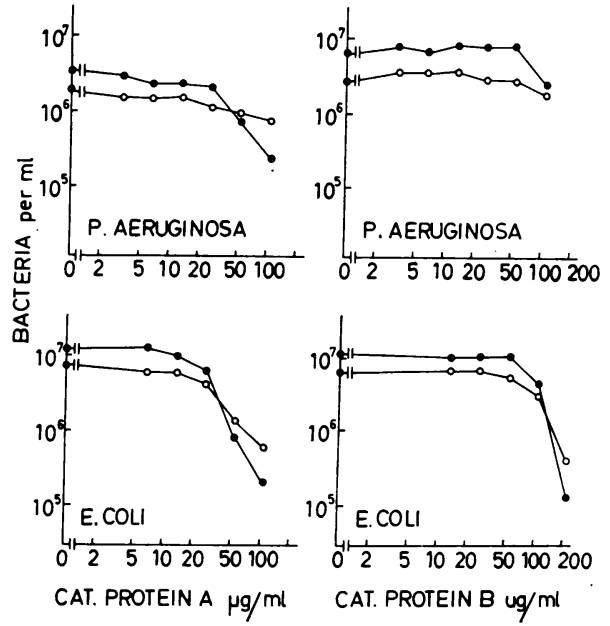

Figure 6 Antimicrobial effect of different concentrations of cationic protein $\mathrm{A}$ and $\mathrm{B}$ on $E$. coli and $P$. aeruginosa. Surviving bacteria are determined by colony counting at $30 \mathrm{~min}(\mathrm{O}-\mathrm{O})$ and $60 \mathrm{~min}(--)$ of incubation. The results shown to the left in the figure are from incubations with cationic protein $\mathrm{A}$ and results shown to the right are from incubations with cationic protein $B$.

The two strains of $S$. faecalis react differently. At a low concentration of cationic protein $(6.8$ and $13.6 \mu \mathrm{g}$ per $\mathrm{ml}$ ) extensive reduction of the number of colonyforming units of both strains is achieved. By increasing the protein concentration the antibacterial effect against the laboratory strain is increased whereas the effect against the clinical strain is decreased; at a concentration of $54.4 \mu \mathrm{g}$ per $\mathrm{ml}$ of cationic protein no antibacterial activity is found. The antibacterial effect against all bacteria tested except the clinical strain of $S$. faecalis is heat stable since heating of the cationic proteins at $90^{\circ} \mathrm{C}$ for $10 \mathrm{~min}$ does not abolish the effect. The effect against the clinical strain of $S$. faecalis is, however, heat labile.

The microbicidal effect of cationic proteins on three different strains of $S$. aureus (502 A, Cowan I, and Wood 46) is compared in Fig. 7. It is apparent that the strain Cowan I exhibits a higher sensitivity than the other two strains.

The antibacterial effects of cationic proteins against two strains of E. coli are compared in Fig. 8. One of the strains is sensitive to the bactericidal effect of serum since $5 \%$ serum causes an extensive reduction of colonyforming units while the other strain is resistant to the effect of serum. The antibacterial activity of cationic proteins is, however, similar for both strains.

Experiments were conducted to compare the microbicidal effect of cationic proteins with that of histones. Lysine-rich histones at a concentration of $200 \mu \mathrm{g} / \mathrm{ml}$ cause a reduction in colony-forming units of $S$. aureus 


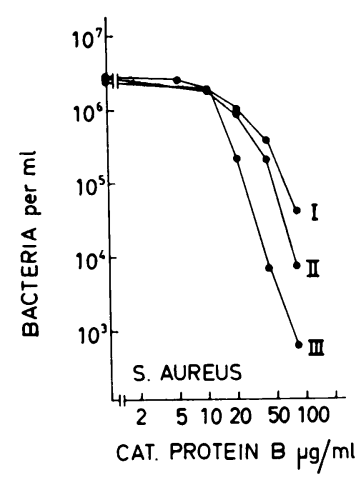

Figure 7 Antimicrobial effect of cationic protein B against three different strains of $S$. aureus. Surviving bacteria are determined by colony counting at $60 \mathrm{~min}(-\bullet)$. The strains are designated "I" (502 A), "II" (Wood 46), and "III" (Cowan I).

502 A from $2.3 \times 10^{8}$ to $1.6 \times 10^{5}$ while cationic protein $A$ at a concentration of $107 \mu \mathrm{g} / \mathrm{ml}$ gives a reduction from $2.3 \times 10^{6}$ to $6.5 \times 10^{8} \mathrm{U} / \mathrm{ml}$. The microbicidal effect of arginine-rich histones is even lower than that of lysine-rich histones.

\section{DISCUSSION}

The present study has demonstrated a potential microbicidal system of the human granulocyte to consist of a group of cationic proteins previously isolated (11). So far the only significant difference found between the four protein components included is in electrophoretic mobility (11), indicating differences in ionic charge. Since the cationic proteins have a chymotrypsin-like esterase activity (15), it might be possible that the microbicidal effect is due to the enzyme properties of the proteins. It is found, however, that the antimicrobial
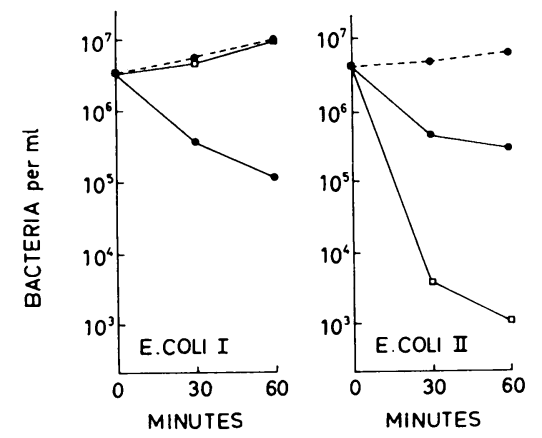

FIGURE 8 Antimicrobial effect of cationic protein $A$ on two clinical isolates from urine of $E$. coli (designated "I" and "II"). Bacteria are incubated with $140 \mu \mathrm{g} / \mathrm{ml}$ cationic protein $\mathrm{A}(-\bullet)$. A control is run without cationic protein (--- For comparison the effect of $5 \%$ human serum is also shown ( $\square-\square)$. activity against several bacterial species is not inhibited by heating, which inhibits the esterase activity (15). Obviously the microbicidal effect demonstrated in these instances is independent of the esterolytic activity. Exception to the heat stability of the antimicrobial activity is shown, however, since the killing of one strain of $S$. faecalis is due to heat-labile properties of the cationic proteins. The dependence on the ionic strength with inhibition of the antimicrobial activity at a high salt concentration points to the possibility of an ionic interaction between the proteins and the bacterial surface relevant to the mechanism of killing. Thus, the sensitivity of the microorganisms may be determined by properties of the microbial envelopes. Generally, Grampositive bacteria are also found more sensitive than Gram-negative organisms. The three strains of $S$. aureus employed show different susceptibility to the antibacterial action of the cationic proteins. Two of the strains, $502 \mathrm{~A}$ and Cowan I, possess staphylococcal protein A, whereas Wood 46 lacks this surface component. The surface properties that are determined by staphylococcal protein A probably have little influence on the susceptibility to cationic proteins as $502 \mathrm{~A}$ was more, and Cowan I less, sensitive than Wood 46. The properties of the Gram-negative envelope of $E$. coli that determine the susceptibility of the organism to the lytic action of human serum are obviously not of importance for the reaction with cationic protein since the two strains of $E$. coli compared show approximately the same sensitivity to cationic proteins but differ considerably in susceptibility to human serum.

The cationic proteins of rabbit granulocytes have been implicated in several biological activities. In addition to cytotoxic actions against bacteria (10), permeability-increasing capabilities have been shown (16). Zeya and Spitznagel (17) suggest that the antibacterial activity is mediated by damage to the cell membrane and/or an inhibition of aerobic respiration. It is well known that histones have microbicidal effects (18) as confirmed in the present study. Both histones and cationic proteins from rabbit granulocytes interfere with mitochondrial respiration (19). Cationic proteins of human granulocytes might have similar properties. Histones exhibit, however, a lower killing capacity than the granule proteins.

The microbicidal activity of the cationic proteins is independent of previously described systems responsible for bactericidal activity in human granulocytes, e.g., the hydrogen peroxide myeloperoxidase complex (1) or superoxide $(20)$. The latter mechanisms are operative only when oxygen is available to the cell. As demonstrated by Mandell (21) anaerobic human granulocytes are able to kill several microorganisms like Staphylococcus epidermidis, Enterococcus, and $P$. aeruginosa 
while organisms like $S$, aureus and $E$. coli are not killed normally by anaerobic phagocytes. Granulocytes from patients with CGD have an abnormal metabolic response to phagocytosis including a markedly reduced oxygen consumption and hydrogen peroxide generation (3). Nevertheless, such cells manifest an intact ability to kill some organisms, e.g., Streptococci (4), Lactobacilli (5), Pneumococci (6), and certain species of Candida (22). The explanation often given is that the bacteria mentioned do succumb after ingestion due to their own elaboration of hydrogen peroxide (5) substituting for defective production of this substance by the granulocyte. Recent work by Shohet et al. (23) demonstrated that CGD cells killed peroxide-positive wild pneumococci much more effectively than a peroxide-deficient mutant, suggesting that peroxidative mechanisms are required for intraphagocytic killing of these species. At the present time, it is not known whether the cationic proteins are involved in killing of microorganisms normally killed in CGD granulocytes. The second mechanism of candidacidal activity of human neutrophils described by Lehrer $(12,22)$ could be identical with the microbicidal system of the present work. The availability of this antimicrobial mechanism was suggested to provide an explanation for the ability of myeloperoxidase-deficient neutrophils and those from patients with CGD to kill certain species of Candida (22).

A $\mathrm{pH}$ optimum near neutrality of the antimicrobial activity raises questions as to the existing $\mathrm{pH}$ within the phagocytic vacuole of the granulocyte. Using indicator dyes, Metchnikoff (24) and Rous (25) conclude that the intracellular $\mathrm{pH}$ of various mammalian phagocytizing cells might be as low as 3.0. Recently, Jensen and Bainton (26), utilizing similar techniques, demonstrated temporal changes in the phagocytic vacuole of rat peritoneal exudate cells during phagocytosis; within $3 \mathrm{~min}$ $\mathrm{pH}$ dropped to 6.5 , and within $7-15 \mathrm{~min}$ it dropped to 4.0. There is only one analogous study available on human granulocytes (27); a maximum $\mathrm{pH}$ depression in the phagocytic vacuole to $6.0-6.6$ is reported. The small decrease thus found of intravacuolar $\mathrm{pH}$ in human cells as compared to other mammalian leukocytes indicates important species differences. It should be emphasized that several major granule components of human cells consist of proteases, e.g. elastase (28), collagenase (29), and the chymotrypsin-like activity of the cationic proteins (15), operating maximally at neutral $\mathrm{pH}$. Such proteases are not found in rabbit or guinea pig granulocytes, which contain cathepsins with an acid $\mathrm{pH}$ optimum. The operation of the cationic proteins of human granulocytes at a neutral $\mathrm{pH}$ would not be inconsistent with a proposed role for these substances in the interaction with ingested microorganisms. The anti- bacterial activity might be exercised early during phagocytosis before a significant drop in $\mathrm{pH}$ has taken place.

Biochemical and morphological studies of granulocytes from several species have revealed two types of cytoplasmic granules, namely, peroxidase-positive (azurophil or primary granules) and peroxidase-negative (specific or secondary granules) (30-33). The cationic proteins of rabbit polymorphonuclear leukocytes are associated with the peroxidase-containing granules (32). Electrophoretic analysis carried out by Dewald et al. (34) on granule fractions obtained by isopycnic centrifugation showed that the most strongly cationic proteins of both human and rabbit granulocytes were confined to the azurophil granules. Recently we have shown the chymotrypsin-like cationic proteins of this study to be localized exclusively in the azurophil granules." Studies by Bainton (35) on rabbit granulocytes indicate that the two types of granules discharge their content in a sequential manner, specific granules fusing with the phagocytic vacuole before azurophil granules. The optimal conditions for the action of the cationic proteins in the phagocytic vacuole might vary with time after ingestion. Furthermore, recent studies by Leffell and Spitznagel (36) emphasize that relatively more of the specific granule proteins were released into the medium during phagocytosis, whereas more of the azurophil proteins were associated with the phagosomes.

\section{ACKNOWLEDGMENTS}

The technical assistance of Mrs. M. B. Håkansson, A. Lundquist, and A. S. Nichols is greatly appreciated.

This study was supported by the Unit for Community Care Sciences of the National Board of Health and Social Welfare at Dalby, the Swedish Cancer Society, and the Medical Faculty, University of Lund.

${ }^{2}$ Ohlsson, K., I. Olsson, and J. K. Spitznagel. 1975. Subcellular localization of chymotrypsin-like cationic proteins, collagenase and elastase in human neutrophilic polymorphonuclear leukocytes. To be published.

\section{REFERENCES}

1. Klebanoff, S. J. 1970. Myeloperoxidase: contribution to the microbicidal activity of intact leukocytes. Science (Wash. D. C.). 169 : 1095-1097.

2. Elsbach, P. 1973. On the interaction between phagocytes and microorganisms. N. Engl. J. Med. 289: 846-852.

3. Holmes, B., A. R. Page, and R. A. Good. 1967. Studies of the metabolic activity of leukocytes from patients with a genetic abnormality of phagocytic function. $J$. Clin. Invest. 46 : 1422-1432.

4. Kaplan, E. L., T. Laxdal, and P. G. Quie. 1968. Studies of polymorphonuclear leukocytes from patients with chronic granulomatous disease of childhood: bactericidal capacity for streptococci. Pediatrics. 41: 591-599.

5. Klebanoff, S. J., and L. R. White. 1969. Iodination defect in the leukocytes of a patient with chronic granulo- 
matous disease of childhood. N. Engl. J. Med. 280: 460-466.

6. Mandell, G. L., and E. W. Hook. 1969. Leukocyte function in chronic granulomatous disease of childhood. Studies on a seventeen year old boy. Am. J. Med. 47: 473-486.

7. Lehrer, R. I., and M. J. Cline. 1969. Leukocyte myeloperoxidase deficiency and disseminated candidiasis: the role of myeloperoxidase in resistance to Candida infection. J. Clin. Invest. 48: 1478-1488.

8. Lehrer, R. I., J. Hanifin, and M. J. Cline. 1969. Defective bactericidal activity in myeloperoxidase-deficient human neutrophils. Nature (Lond.). 223: 78-79.

9. Hirsch, J. G. 1960. Further studies on preparation and properties of phagocytin. J. Exp. Med. 111: 323-337.

10. Zeya, H. I., and J. K. Spitznagel. 1966. Antimicrobial specificity of leukocyte lysosomal cationic proteins. Science (Wash. D. C.). 154: 1049-1051.

11. Olsson, I., and P. Venge. 1974. Cationic proteins of human granulocytes. II. Separation of the cationic proteins of the granules of leukemic myeloid cells. Blood. $44: 235-246$.

12. Lehrer, R. I., K. Mitchell, and R. Hake. 1973. Identification of a second fungicidal mechanism in the human neutrophil (PMN). Clin. Res. 21: 605. (Abstr.)

13. Rindler, R., and H. Braunsteiner. 1973. Soluble proteins from human leukocyte granules. I. Esterase activity of cationic proteins. Blut. $27: 26-32$.

14. Arvidson, S., R. Holme, and T. Wadström. 1971. Influence of cultivation conditions on the production of extracellular proteins by Staphylococcus aureus. Acta. Pathol. Microbiol. Scand. Sect. B Microbiol. Immunol. 79: 399-405.

15. Odeberg, H., I. Olsson, and P. Venge. 1975. Cationic proteins of human granulocytes. IV. Esterase activity. Lab. Invest. 32 : 86-90.

16. Ranadive, N. D., and C. G. Cochrane. 1968. Isolation and characterization of permeability factors from rabbit neutrophils. J. Exp. Med. 128: 605-622.

17. Zeya, H. I., and J. K. Spitznagel. 1966. Cationic proteins of polymorphonuclear leukocyte lysosomes. II. Composition, properties and mechanism of antibacterial action. J. Bacteriol. 91: 755-762.

18 Hirsch, J. G. 1958. Bactericidal action of histone. J. Exp. Med. 108: 925-944.

19. Penniall, R., and H. I. Zeya. 1971. The effects of cationic proteins of rabbit polymorphonuclear leukocyte lysosomes on the respiratory activity of liver mitochondria. Biochem. Biophys. Res. Commun. 45: 6-13.

20. Babior, B. M., R. S. Kipnes, and J. T. Curnutte. 1973. Biological defense mechanisms. The production by leukocytes of superoxide, a potential bactericidal agent. $J$. Clin. Invest. 52 : 741-744.

21. Mandell, G. L. 1974. Bactericidal activity of aerobic and anaerobic polymorphonuclear neutrophils. Infect. Immun. 9 : 337-341.
22. Lehrer, R. I. 1972. Functional aspects of a second mechanism of candidacidal activity by human neutrophils. J. Clin. Invest. 51 : 2566-2572.

23. Shohet, S. B., J. Pitt, R. L. Baehner, and D. G. Poplack. 1974. Lipid peroxidation in the killing of phagocytized pneumococci. Infect. Immun. 10: 1321-1328.

24. Metchnikoff, E. 1893. Lectures on the Comparative Pathology of Inflammation. Kegan, Paul, Trench, Trübner \& Co., Ltd., London.

25. Rous, P. 1925. The relative reaction within living mammalian tissues. II. On the mobilization of acid material within cells, and the reaction as influenced by the cell state. J. Exp. Med. 41: 399-411.

26. Jensen, M. S., and D. F. Bainton. 1973. Temporal changes in $\mathrm{pH}$ within the phagocytic vacuole of the polymorphonuclear neutrophilic leukocyte. J. Cell Biol. 56: 379-388.

27. Mandell, G. L. 1970. Intraphagosomal $\mathrm{pH}$ of human polymorphonuclear neutrophils. Proc. Soc. Exp. Biol. Med. 134 : 447-449.

28. Ohlsson, K., and I. Olsson. 1974. The neutral proteases of human granulocytes. Isolation and characterization of granulocyte elastases. Eur. J. Biochem. 42: 519-527.

29. Ohlsson, K., and I. Olsson. 1973. The neutral proteases of human granulocytes. Isolation and partial characterization of two granulocyte collagenases. Eur. J. Biochem. 36: 473-481.

30. Baggiolini, M., J. G. Hirsch, and C. de Duve. 1969. Resolution of granules from rabbit heterophil leukocytes into distinct populations by zonal sedimentation. J. Cell Biol. 40 : 529-541.

31. Bainton, D. F., J. I. Ullyot, and M. G. Farquhar. 1971. The development of neutrophilic polymorphonuclear leukocytes in human bone marrow. Origin and content of azurophil and specific granules. J. Exp. Med. 134: 907-934.

32. Zeya, H. I., and J. K. Spitznagel. 1971. Characterization of cationic protein-bearing granules of polymorphonuclear leukocytes. Lab. Invest. 24: 229-236.

33. Spitznagel, J. K., F. G. Dalldorf, M. S. Leffell, J. D. Folds, I. R. H. Welsh, M. H. Cooney, and L. E. Martin. 1974. Character of azurophil and specific granules purified from human polymorphonuclear leukocytes. Lab. Invest. 30: 774-785.

34. Dewald, B., R. Rindler-Ludwig, U. Bretz, and M. Baggiolini. 1975. Subcellular localization and heterogeneity of neutral proteases in neutrophilic polymorphonuclear leukocytes. J. Exp. Med. 141: 709-723.

35. Bainton, D. F. 1973. Sequential degranulation of the two types of polymorphonuclear leukocyte granules during phagocytosis of microorganisms. J. Cell Biol. 58: $249-264$.

36. Leffell, M. S., and J. K. Spitznagel. 1974. Intracellular and extracellular degranulation of human polymorphonuclear azurophil and specific granules induced by immune complexes. Infect. Immun. 10: 1241-1249. 